\title{
Improving Grain Micronutrient Content of Durum Wheat (Triticum turgidum var. durum) through Agronomic Biofortification to Alleviate the Hidden Hunger
}

\author{
Anteneh Agezew Melash ${ }^{1}{ }^{1}$ and Dejene Kassahun Mengistu $\mathbb{i D}^{2,3}$ \\ ${ }^{1}$ Debark University, College of Agriculture and Environmental Science, Department of Horticulture, P.O. Box 90, North Gondar, \\ Debark, Ethiopia \\ ${ }^{2}$ Mekelle University, College of Dryland Agriculture and Natural Resource, \\ Department of Dryland Crop and Horticultural Science, P.O. Box 231, Mek'ele, Ethiopia \\ ${ }^{3}$ Bioversity International, Ethiopia Office, Addis Ababa 1000, Ethiopia \\ Correspondence should be addressed to Anteneh Agezew Melash; antenehagezew2008@gmail.com
}

Received 19 July 2019; Revised 15 November 2020; Accepted 5 December 2020; Published 14 December 2020

Academic Editor: Othmane Merah

Copyright (c) 2020 Anteneh Agezew Melash and Dejene Kassahun Mengistu. This is an open access article distributed under the Creative Commons Attribution License, which permits unrestricted use, distribution, and reproduction in any medium, provided the original work is properly cited.

\begin{abstract}
Improvement of durum wheat grain quality through agronomic biofortification becomes a priority research area and an effective route to combat malnutrition. An experiment was conducted to evaluate the effect of micronutrient application to different varieties of durum wheat and seeding rate on final harvest grain quality under different growing locations. The treatments were arranged in split-split plot design where the varieties were assigned in the main plot, micronutrients into the subplots, and seeding rate into the sub-subplots. Each variety was sown at four levels of seeding rates and treated with $\mathrm{ZnSO}_{4}$ and $\mathrm{FeSO}_{4}$ applied foliarly, both at a rate of $25 \mathrm{Kg} \mathrm{ha}^{-1}$ during flowering. Micronutrients were applied in the form of $\mathrm{ZnSO}_{4} 7 \mathrm{H}_{2} \mathrm{O}$ and $\mathrm{FeSO}_{4} 7 \mathrm{H}_{2} \mathrm{O}$. The study confirmed that application of $25 \mathrm{Kg} \mathrm{ha}^{-1} \mathrm{ZnSO}_{4}$-containing fertilizer has increased mineral content from $33.04 \mathrm{mg} \mathrm{Kg}^{-1}$ to $56.73 \mathrm{mg} \mathrm{kg}^{-1}$. The tested durum wheat varieties significantly differ in their capacity to accumulate grain $\mathrm{Zn}$ and Fe concentrations. Higher amount of $\mathrm{Zn}\left(20 \mathrm{mg} \mathrm{kg}^{-1}\right)$ and $\mathrm{Fe}\left(10 \mathrm{mg} \mathrm{kg}^{-1}\right)$ were accumulated by the landrace 208304 than by Asassa, an improved commercial variety. Increasing seeding rate from $100-175 \mathrm{Kg} \mathrm{ha}^{-1}$ has reduced grain $\mathrm{Zn}$ and Fe concentrations. Grain mineral concentration was significantly lower at the Mekelle location than at the Melfa location. It can be concluded that foliar application of $\mathrm{ZnSO}_{4}$ and $\mathrm{FeSO}_{4}$ to the landrace, acc.208304, combined with $125 \mathrm{Kg}$ seeds ha ${ }^{-1}$ can produce better $\mathrm{Zn}$ and Fe denser durum wheat grain. This will help to combat the hidden hunger, especially in resource poor countries, where fortified foods are limited in access and unaffordable by small-scale farmers.
\end{abstract}

\section{Introduction}

The twenty-first century has faced a challenge with malnutrition, as more than 1.5 billion people are burdened with one or more forms of micronutrient deficiency [1]. Narrowing the prevalence of micronutrient deficiency down to Ethiopia, especially in rural areas of Amhara and Tigrai are the most severely affected regions; about half of pregnant women and $20 \%$ of children under five are vulnerable groups $[2,3]$. The poor dietary diversification, monotonous wheat-based food consumption with low concentration, loss of crop genetic diversity, and climate change coupled with soil micronutrient depletion could be responsible for high malnutrition rate. An excessive intake of wheat-based products is frequently reported as a principal reason for micronutrient malnutrition, as wheat is innately low in zinc content and high in phytate, which further limits the bioavailability of zinc in the edible portion of wheat [4]. This food habit therefore affects the human health condition through altered grain nutritional composition. Consequently, this leads to diverse health effects such as poor growth and development and reduced immunity and tissue development, as well as poor health and increased 
risk of death [5]. Thus, nutritional knowledge and food habit may play an important role through moderating the influence of household food insecurity on the diet and accordingly on nutritional outcomes.

The intervention designed to reduce the extent of micronutrient deficiency and associated health problems ranges from dietary diversification, industrial fortification, pharmaceutical supplementation, and genetic biofortification. These interventions are an immediate and effective route to ameliorate micronutrient concentration in the human body and edible plants as well. The successful implementation of these exogenous strategies however is limited due to limited access and affordability for resource-poor farmers, failure to reach all individuals, and unavailability $[6,7]$. Thus, agronomic biofortification (micronutrient fertilization) can be a complimentary and effective way of agricultural strategy to improve grain nutritional composition [8].

Agronomic biofortification is the application of micronutrient-containing mineral fertilizers to ameliorate concentration of essential nutrients in the edible part of food crops [9]. It can be achieved through application of micronutrient-containing fertilizers to the soil or foliarly directly to the crop leaves during specific developmental stage. However, its effectiveness is determined by the application method, growing environment, varietal response difference, and other agronomic practices [10]. In spite of its importance to reduce micronutrient deficiency, the study on how agronomic practices influence effectiveness of agronomic biofortification is scanty in northern Ethiopia. For this reason, this research was conducted the extent to which agronomic biofortification is influenced by the main and interaction effect of seeding rate, durum wheat varieties, and divergence in growing locations. Wheat varieties respond differently to the application of micronutrients during growing period probably due to their difference in micronutrient use efficiency. It has been shown that one of the effective routes to improve grain mineral composition is the application of zinc-containing fertilizer either to the soil or applying foliarly and combined use of soil and foliar application [11]. Foliar application was perceived to be more effective in increasing grain $\mathrm{Zn}$ and Fe concentrations in different edible crops. In wheat, the foliar-based micronutrient-containing fertilizer was reported to be effective in increasing grain zinc and iron concentrations compared to the soil-based application [12]. It is probably through the fact that foliar application of micronutrient fertilizers stimulated more nutrient uptake in the edible plant portion of cereal crops [13]. This research is, therefore, initiated (i) to evaluate the effect of foliar application of zinc- and iron-containing fertilizers on grain zinc and iron concentrations and (ii) to appraise the effectiveness of agronomic biofortification as determined by adjustment of seeding rate and difference in durum wheat varieties under two divergent agro-ecologies.

\section{Materials and Methods}

2.1. Description of the Study Areas. The field experiment was conducted at two locations in northern Ethiopia, at Mekelle University (MU) Research Station and Melfa Farmers
Training Center (FTC). The first location MU Research Station is suited between $13^{\circ} 30^{\prime} \mathrm{N}$ and $39^{\circ} 29^{\prime} \mathrm{E}$. It has bimodal type of rainfall where 70 to $80 \%$ falls during July and August [14]. The other experimental location "Melfa" Farmers Training Center is also located at $13^{\circ} 39^{\prime} \mathrm{N}$ and $39^{\circ} 10^{\prime} \mathrm{E}$. It receives an annual rainfall of $762 \mathrm{~mm}$ [15]. Both experimental locations are deficient in soil zinc and iron microelements [16].

2.2. Experimental Design and Treatments. The experiment was laid out in the split-split plot design. The varieties were assigned to the main plots, seeding rates to the subplots and micronutrients to the sub-subplots. The two tested durum wheat varieties were Asassa, an improved commercial variety, and farmer variety/landrace acc.208304. The varieties were planted at four levels of seeding rates $(100,125,150$, and $175 \mathrm{~kg} \mathrm{ha}^{-1}$ ) and treated with two levels of micronutrients including $\mathrm{ZnSO}_{4}$ and $\mathrm{FeSO}_{4}$. Micronutrients were applied in the form of $\mathrm{ZnSO}_{4} 7 \mathrm{H}_{2} \mathrm{O}$ and $\mathrm{FeSO}_{4} 7 \mathrm{H}_{2} \mathrm{O}$. For each experimental plot, $20 \mathrm{~g}$ of $\mathrm{Zn}$ and $\mathrm{Fe}$ was applied after diluting in $1 \mathrm{~L}$ of water. The net plot size of subplots and subsubplots was $4.4 \mathrm{~m} \times 2.5 \mathrm{~m}$ and $1.2 \mathrm{~m} \times 2.5 \mathrm{~m}$, respectively. Each subplot and sub-subplots were separated by gang spacing of $0.5 \mathrm{~m}$ and $0.4 \mathrm{~m}$, respectively. The spacing between replications was $0.8 \mathrm{~m}$. Iron sulfate $\left(\mathrm{FeSO}_{4}\right)$ and zinc sulfate $\left(\mathrm{ZnSO}_{4}\right)$ were foliarly applied during flowering at a rate of $25 \mathrm{~kg} \mathrm{ha}^{-1}$. All experimental plots were equally treated with $46 \mathrm{~kg} \mathrm{ha}^{-1}$ of nitrogen and $20 \mathrm{~kg} \mathrm{ha}^{-1}$ of phosphorus. The nitrogen was split into two doses where the first half dose together with phosphorus was applied at planting. The remaining half dose of Nitrogen was applied at the tillering stage. Weed control was performed manually and maintained throughout the cropping period.

2.2.1. Grain Mineral Concentration Analysis. From the final grain harvested from each location, 20 gram of grain was sampled and sent to EZANA Mining Development PLC Laboratory for analysis of the grain mineral content. The grains were digested using Perten Laboratory Mill 120 to a standard sieve of $0.8 \mathrm{~mm}$ and grain zinc and iron concentrations were determined using Varian AA240FS Fast Sequential Atomic Absorption Photometer, a complete automated PC-controlled true double beam atomic absorption, which has fast sequential operation for fast multielement flame AA determinations, operated with SpectrAA Base and PRO software version. All samples were digested in an automated digestion chamber. The procedure used to measure $\mathrm{Zn}$ and Fe concentrations $\left(\mathrm{mg} \mathrm{kg}^{-1}\right)$ in the samples was as described by Kunda et al. [17].

2.3. Statistical Data Analysis. The raw data, after checking for normality and homogeneity, was analyzed for variance using GenStat statistical software ver. 14 [18], following the split-split plot design structure. This analysis allowed us to examine the main effects and the interaction effect between genotypes, seeding rates, and applied micronutrients. For significant effects, means were separated using least 
significance difference (LSD) at 5\% significance level. Duncan's multiple range test (DMRT) was employed for comparison of the various interaction means presented in various graphs. While some of the results presented in tabular form, most interaction results were presented as graph to make its visualization easier. The mean values were used to construct the graphs using excel graphing features. Bars representing treatments combination means were designated by error bars and separated by letters where bars separated by different letters were significantly different from each other.

\section{Results and Discussion}

3.1. Grain $\mathrm{Zn}$ and $\mathrm{Fe}$ Concentrations as Affected by Foliar Microfertilizers Application. The foliar application of $\mathrm{ZnSO}_{4}$ at the flowering stage has significantly $(p<0.001)$ enhanced grain $\mathrm{Zn}$ concentration from $33.04 \mathrm{mg} \mathrm{kg}^{-1}$ to $56.73 \mathrm{mg} \mathrm{kg}^{-1}$ (Figure 1). Such increase in $\mathrm{Zn}$ concentration in wheat grain, which ultimately improve wheat nutritional value, encourages microfertilizers application with small additional cost. The finding agreed with Cakmak et al.'s [4] finding which reported $11 \%$ grain $\mathrm{Zn}$ concentration gain under $\mathrm{ZnSO}_{4}$ fertilization. Zhangmin et al. [19] verified that foliar-based fertilization of zinc is more phloem mobile and consequently zinc readily translocated into developing grains in wheat. In addition, improvement in grain $\mathrm{Zn}$ concentration under foliar zinc fertilization could be due to reduction in grain phytic acid accumulation [19]. As the application of Zn-containing fertilizers decreases, both uptake and accumulation of phosphorus consequently decrease in grain phytic acid accumulation [20] and ultimately increase the bioavailability of zinc in the grain. The concentration of zinc in wheat grain highly depends on retranslocation of zinc from vegetative tissues during the reproductive stages [21]. On the other hand, the application of $\mathrm{FeSO}_{4}$ did not impact grain iron concentration. The mean value of $\mathrm{Fe}$ concentration was not significantly different from the unfertilized plot (Figure 1). This could be due to the characteristics of the applied fertilizer, since iron is less phloem mobile in cereals and retained in older leaves $[22,23]$.

The agronomic biofortification to address nutrient deficiencies is an enticing concept, but there is much to understand about the factors that determine its effectiveness. The current study showed that agronomic biofortification of zinc and iron is affected by crop variety, seeding rate, and growing locations.

\subsection{Determinant Factors of Grain Zn and Fe Concentrations}

3.2.1. The Varietal Difference. The concentrations of $\mathrm{Zn}$ and Fe were significantly $(p<0.001)$ affected by varietal differences. The maximum grain zinc concentration was accumulated more by the farmer variety "208304" $\left(67.19 \mathrm{mg} \mathrm{kg}^{-1}\right)$ than Asassa, the improved variety $\left(46.27 \mathrm{mg} \mathrm{kg}^{-1}\right.$ ) (Figure 2). This implies that the farmer variety accumulated $20.92 \mathrm{mg} \mathrm{kg}^{-1}$ of $\mathrm{Zn}$ more than the improved variety. This difference in varietal micronutrients accumulation under similar growing conditions is due to

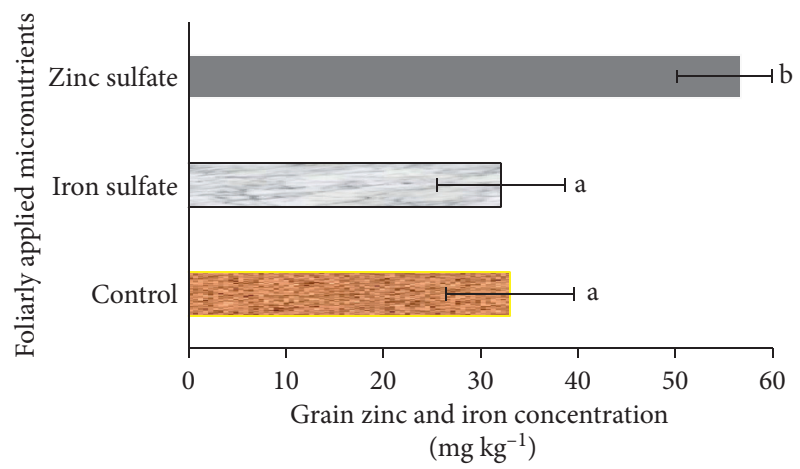

FIgURE 1: The effect of foliar application of $\mathrm{ZnSO}_{4}$ and $\mathrm{FeSO}_{4}$ on grain $\mathrm{Zn}$ and $\mathrm{Fe}$ concentrations $\left(\mathrm{mg} \mathrm{kg}^{-1}\right)$. Bars labeled with different letters are significantly different from each other.

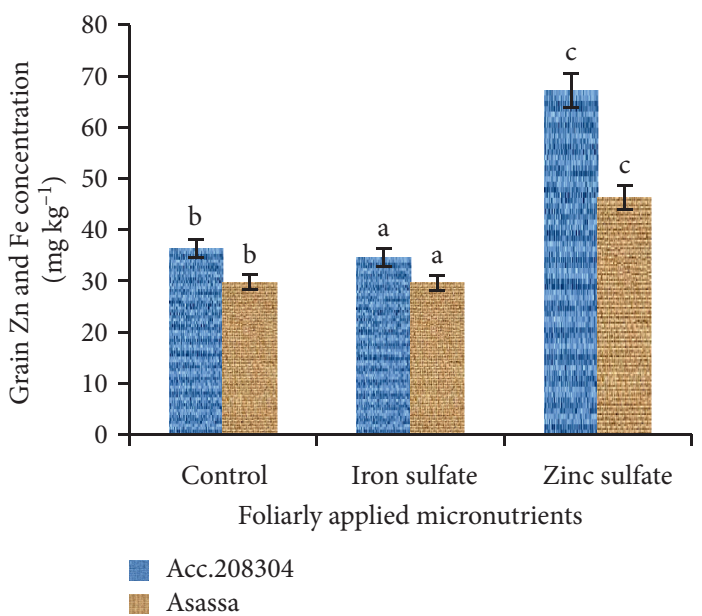

FIgURE 2: Response of the tested varieties to the applied zinc and iron fertilizers under deficit soil condition $\left(\mathrm{mg} \mathrm{kg}^{-1}\right)$.

genetic difference of the varieties. This may indicate that ameliorating grain mineral concentration could also be possible through genetic biofortification through wise exploitation of existing crop genetic resources. The genetic variation in crops for micronutrient accumulation was reported by Melash et al. [24] and Mathpal et al. [25].

The differential accumulation of $\mathrm{Zn}$ by varieties could be related to their grain phytate content [26]. Therefore, choice of micronutrient efficient varieties may have a special advantage to reduce micronutrient deficiency in humans. The target level of zinc concentration required to combat deficiency of zinc in wheat grain was estimated to be $45 \mathrm{mg} \mathrm{kg}^{-1}$ [27]. Taking the ever-increasing global food demand and high prevalence malnutrition into consideration, increasing grain $\mathrm{Zn}$ concentration in high-yielding wheat variety is important. Hence, the target level to reduce human micronutrient deficiency could be achieved by using the genetic resource such as the farmer variety acc.208304 (Figure 2). Exploiting crop genetic resource to enhance mineral density under deficit soils fertility can be an alternative way to overcome the problem associated with micronutrient deficiency. 
3.2.2. Seeding Rate. The other important factor determining the effectiveness of agronomic biofortification was the seeding rate. The current study identified a seeding rate of $125 \mathrm{~kg} \mathrm{ha}^{-1}$ as optimal for better accumulation of $\mathrm{Zn}$ and Fe in durum wheat grain (Table 1). As the seeding rate increases from 100 to $175 \mathrm{~kg} \mathrm{ha}^{-1}$, the concentrations of $\mathrm{Zn}$ and $\mathrm{Fe}$ in the grain declined (Table 1). From the result, it seems that grain mineral composition has an inverse relationship with seeding rate beyond $125 \mathrm{~kg} \mathrm{ha}^{-1}$. This could be due to the interplant competition for available resources such as soil moisture which reduce the uptake and translocation of minerals when water is deficient in the root zone. We have previously reported an inverse relationship between seeding rate and grain quality traits such as grain protein content and gluten content, and Zeleny index was observed [24].

3.2.3. Growing Environments (Locations). Test location was found to be the other important factor determining the accumulation of $\mathrm{Zn}$ and $\mathrm{Fe}$ in durum wheat grain. Grains harvested from MU and Melfa locations have accumulated significantly $(p<0.001)$ different amounts of $\mathrm{Zn}$ and $\mathrm{Fe}$ (Figure 3).

Both $\mathrm{Zn}$ and $\mathrm{Fe}$ grain concentrations were higher at Melfa than at MU under similar soil and crop management practices. MU growing conditions might be constrained the uptake, translocation, and accumulation of micronutrients in grains. MU location is usually subjected to terminal drought and has poor soil fertility level compared to Melfa [24]. It might be inferred that grain mineral concentration might be affected by soil and other climatic characteristics of the specific location as reported by Abrar et al. [28]. The soil chemical compositions such as high $\mathrm{pH}$, high calcium carbonate content, and poor organic matter content reduce zinc bioavailability and zinc root uptake [29].

3.2.4. GEI Effect on Zn Concentration. The interaction effects between varieties, seeding rate, and microfertilizers application (GEI) were only presented for $\mathrm{Zn}$ as the effect did not significantly affect Fe concentration. Zn concentration in durum wheat grain was subjected to the interaction effect between varieties, seeding rate, and applied microfertilizers (Figure 4). This interactions effect has significantly $(p<0.001)$ affected grain mineral accumulation. The highest $\mathrm{Zn}$ concentration was obtained from farmer variety acc. 208304 at seeding rate of $125 \mathrm{~kg} \mathrm{ha}^{-1}$ under $\mathrm{ZnSO}_{4}$ treatment (Figure 4). On the other hand, higher $\mathrm{Zn}$ concentration for the improved variety, Asassa, was obtained from $100 \mathrm{~kg}$ ha to 1 seeding rate treated with $\mathrm{ZnSO}_{4}$. This implies that ameliorating grain mineral concentration requires varietal selection and determination of optimal seeding rate for enhanced uptake and translocation of applied microfertilizers.

The two varieties differentially interact with the seeding rate to accumulate $\mathrm{Zn}$ in their grain (Figure 5). The farmer variety, acc.208304, has accumulated $63.38 \mathrm{mg} \mathrm{kg}^{-1}$ of $\mathrm{Zn}$ at $125 \mathrm{~kg} \mathrm{ha}^{-1}$ seeding rate. The amount of $\mathrm{Zn}$ accumulated at higher seeding rates (150 and $175 \mathrm{~kg} \mathrm{ha}^{-1}$ ) was not statistically different from the unfertilized accumulation
TABLE 1: Interaction effect of seeding rate and applied micronutrients on grain zinc and iron concentrations $\left(\mathrm{mg} \mathrm{kg}^{-1}\right)$.

\begin{tabular}{lcccc}
\hline \multirow{2}{*}{ Micronutrients } & \multicolumn{4}{c}{ Seeding rate $\left(\mathrm{kg} \mathrm{ha}^{-1}\right)$} \\
& 100 & 125 & 150 & 175 \\
\hline Control & 33.11 & 37.57 & 30.23 & 31.26 \\
Zinc sulfate & 52.57 & 71.16 & 52.21 & 50.97 \\
Iron sulfate & 30.99 & 40.13 & 31.96 & 25.24 \\
\hline LSD $_{0.05}$ & & & 8.52 \\
$\mathrm{CV}(\%)$ & & & 5.10 \\
\hline
\end{tabular}

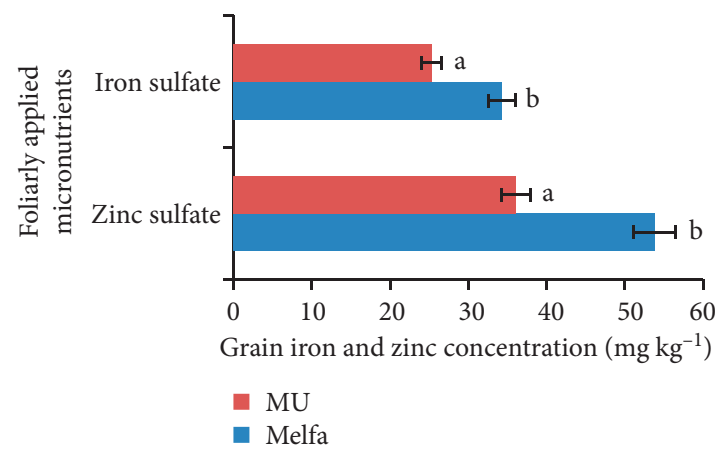

FIGURE 3: Grain $\mathrm{Zn}$ and Fe concentrations $\left(\mathrm{mg} \mathrm{kg}^{-1}\right)$ across test locations. Bars designated by different letters are statistically different from each other.

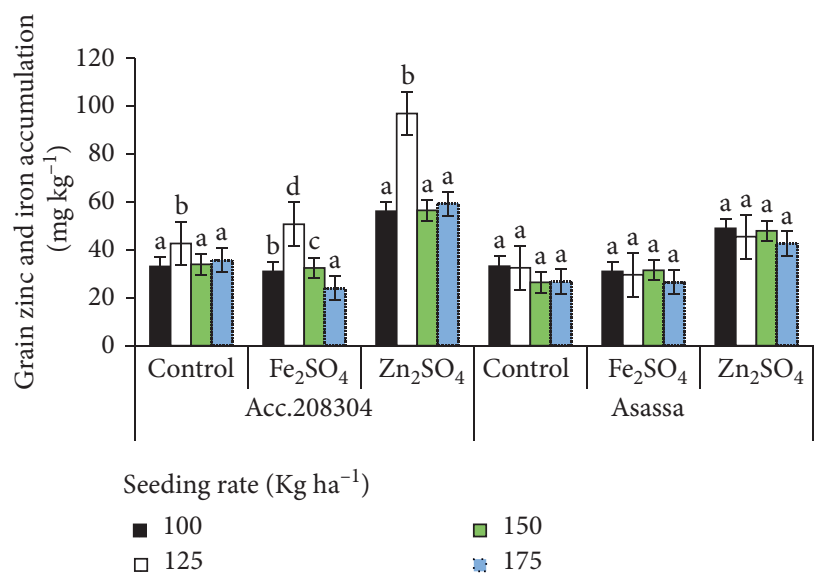

FIgURE 4: Grain $\mathrm{Zn}$ and Fe concentrations $\left(\mathrm{mg} \mathrm{kg}^{-1}\right)$ due to the interaction between varieties, seeding rate, and microfertilizers. Bars separated with different letters are statistically different from each other.

(Figure 5). The improved variety, Asassa, has accumulated less grain $\mathrm{Zn}$ under all seeding rates compared to the farmer variety, acc.208304. For the improved variety, the amount of $\mathrm{Zn}$ concentrated decreased with increasing seeding rate. The interaction between seeding rate and variety significantly affects $\mathrm{Zn}$ concentration of the grain.

It seems that, there is an inverse relationship between grain micronutrients concentration and seeding rate. This universally explains that, there was a steady decrease for grain zinc concentration as the seeding rate increased from 100 to $175 \mathrm{~kg} \mathrm{ha}^{-1}$. Such inverse relationship between 


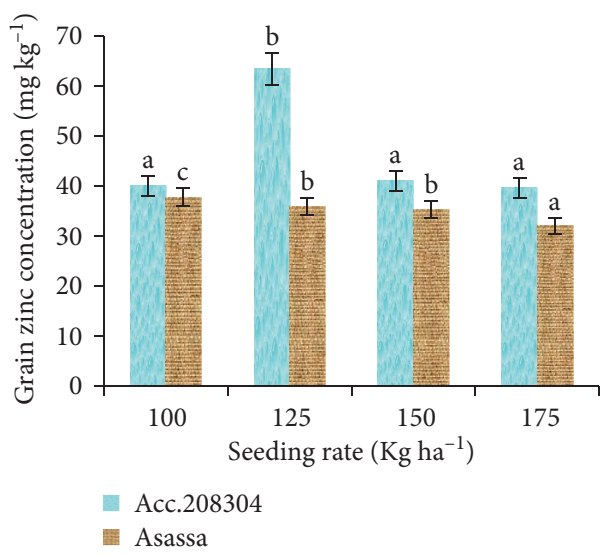

FIGURE 5: Grain $\mathrm{Zn}$ concentration $\left(\mathrm{mg} \mathrm{kg}^{-1}\right)$ due to wheat variety by seeding rate interaction effects. Bars designated with different letters are statistically different.

seeding rate and grain quality traits was reported previously [24]. This study further indicated that for maximum concentration of grain $\mathrm{Zn}$, variety-specific seeding rate recommendation is needed.

\section{Conclusion}

Micronutrients nutrition is one of the potentially amendable factors in human health and well-beings at any stage. These factors could be reduced directly through nutrition-specific intervention and indirectly by nutrition-sensitive interventions. The study indicated that grain zinc and iron concentrations were significantly affected by seeding rate, varietal difference, and test locations. More concentrations of $\mathrm{Zn}$ and $\mathrm{Fe}$ were found in grains harvested from Melfa than from MU. Grain Zn and Fe concentrations decreased as the seeding rate increased from $125 \mathrm{~kg} \mathrm{ha}^{-1}$ to $175 \mathrm{~kg} \mathrm{ha}^{-1}$ and higher $\mathrm{Zn}$ and $\mathrm{Fe}$ were accumulated by the landrace, acc.208304, than the improved variety, Asassa, which implies that farmer varieties could have better genetic potential for micronutrient accumulation. Exploitation of existing genetic resources for natural grain micronutrients accumulation could be an affordable and sustainable approach to mitigate $\mathrm{Zn}$ and $\mathrm{Fe}$ deficiency-related health problems. However, further research is needed as the findings cannot be conclusive from single season experimentation.

\section{Data Availability}

The data used to support the findings of this study are available from the corresponding author upon request.

\section{Conflicts of Interest}

The authors declare that there are no conflicts of interest.

\section{Acknowledgments}

The authors greatly acknowledge DUREP project for providing the two tested durum wheat varieties and
RUFORUM-Wheat Value Chain Project for the financial support provided.

\section{References}

[1] FAO (Food and Agricultural Organization of the United Nations), The State of Food Security and Nutrition in the World: Building Climate Resilience for Food Security and Nutrition, FAO, Rome, Italy, 2018.

[2] M. Anteneh Agezew, D. K. Mengistu, and D. A. Assefa, "Linking agriculture with health through genetic and agronomic biofortification," Agricultural Sciences, vol. 7, no. 5, pp. 295-307, 2016.

[3] G. Kumera, T. Awoke, T. Melese et al., "Prevalence of zinc deficiency and its association with dietary, serum albumin and intestinal parasitic infection among pregnant women attending antenatal care at the University of Gondar Hospital, Gondar, Northwest Ethiopia," BMC Nutrition, vol. 1, no. 1, p. 31, 2015.

[4] I. Cakmak, W. H. Pfeiffer, and B. McClafferty, "Review: biofortification of durum wheat with zinc and iron," Cereal Chemistry Journal, vol. 87, no. 1, pp. 10-20, 2010.

[5] UNICEF, The State of the World's Children. Children, Food and Nutrition: Growing Well in a Changing World, UNICEF, New York, NY, USA, 2019.

[6] S. Gómez-Galera, E. Rojas, D. Sudhakar et al., "Critical evaluation of strategies for mineral fortification of staple food crops," Transgenic Research, vol. 19, no. 2, pp. 165-180, 2010.

[7] R. Hurrell, P. Ranum, S. De Pee et al., "Revised recommendations for iron fortification of wheat flour and an evaluation of the expected impact of current national wheat flour fortification programs," Food and Nutrition Bulletin, vol. 31, no. 1_suppl1, pp. S7-S21, 2010.

[8] G. Velu, I. Ortiz-Monasterio, I. Cakmak, Y. Hao, and R. P. Singh, "Biofortification strategies to increase grain zinc and iron concentrations in wheat," Journal of Cereal Science, vol. 59, no. 3, pp. 365-372, 2014.

[9] A. W. De Valençaa, A. Bakeb, I. D. Brouwerb, and K. E. Giller, "Agronomic biofortification of crops to fight hidden hunger in sub-Saharan Africa," Global Food Security, vol. 12, no. 8-14, 2017.

[10] H. Mao, J. Wang, Z. Wang, Y. Zan, G. H. Lyons, and C. Zhou, "Using agronomic biofortification to boost zinc, selenium, and iodine concentrations of food crops grown on the loess plateau in China," Journal of Soil Science and Plant Nutrition, vol. 14, pp. 459-470, 2013.

[11] A. El-Metwally, N. Khalil, M. El-Fouly, and M. El-Dahshouri, Growth, nutrients uptake and grain yield of some wheat cultivars as affected by zinc application under sandy soil conditions," Journal of Plant Production, vol. 3, no. 5, pp. 773-783, 2012.

[12] Y. Ramzan, M. B. Hafeez, S. Khan et al., "Biofortification with zinc and iron improves the grain quality and yield of wheat crop," International Journal of Plant Production, vol. 14, no. 3 , pp. 501-510, 2020.

[13] Y. Zhang, R. Shi, K. M. Rezaul, F. Zhang, and C. Zou, "Iron and zinc concentrations in grain and flour of winter wheat as affected by foliar application," Journal of Agricultural and Food Chemistry, vol. 58, no. 23, pp. 12268-12274, 2010.

[14] A. Araya, S. D. Keesstra, and L. Stroosnijder, "A new agroclimatic classification for crop suitability zoning in northern semi-arid Ethiopia," Agricultural and Forest Meteorology, vol. 150, no. 7-8, pp. 1047-1064, 2010. 
[15] J. Nyssen, J. Naudts, M. Haile et al., "Soils and land use in the Tigray highlands (northern Ethiopia)," Land Degradation and Development, vol. 19, no. 3, pp. 257-274, 2010.

[16] ATA (Agricultural Transformation Agency), Soil Fertility Status and Fertilizer Recommendation Atlas for Tigray Regional State, Ethiopia, Ministry of agriculture and Ethiopia Agricultural Transformation Agency, Addis Ababa, Ethiopia, 2014.

[17] S. S. Kundu, R. Podder, K. E. Bett, J. J. Schoenau, and A. Vanderberg, "Optimizing seed sample size for zinc and iron analysis of wild and cultivated lentil," Communications in Soil Science and Plant Analysis, vol. 48, no. 13, pp. 1584-1594, 2017.

[18] R. W. Payne, D. A. Murray, S. A. Harding, D. B. Baird, and D. M. Soutar, An Introduction to GenStat for Windows, VSN International Ltd, HemelHempstead, England, 14th edition, 2011.

[19] W. Zhangmin, Q. Liu, F. Pan, L. Yuan, and X. Yin, "Effects of increasing rates of zinc fertilization on phytic acid and phytic acid/zinc molar ratio in zinc bio-fortified wheat," Journal of Field Crop Research, vol. 184, pp. 58-64, 2015.

[20] E. J. M. Joy, A. J. Stein, S. D. Young, E. L. Ander, M. J. Watts, and M. R. Broadley, "Zinc-enriched fertilisers as a potential public health intervention in Africa," Plant and Soil, vol. 389, no. 1-2, pp. 1-24, 2015.

[21] I. Cakmak, M. Kalayci, Y. Kaya et al., "Biofortification and localization of zinc in wheat grain," Journal of Agricultural and Food Chemistry, vol. 58, no. 16, pp. 9092-9102, 2010.

[22] P. Valérie and U. Feller, "Heavy metals in crop plants: transport and redistribution processes on the whole plant level," Agronomy, vol. 5, no. 3, pp. 447-463, 2015.

[23] M. A. Grusak, J. N. Pearson, and E. Marentes, "The physiology of micronutrient homeostasis in field crops," Field Crops Research, vol. 60, no. 1-2, pp. 41-56, 1999.

[24] A. A. Melash, D. K. Mengistu, D. A. Aberra, and T. Alemtsehay, "The influence of seeding rate and micronutrients foliar application on grain yield and quality traits and micronutrients of durum wheat," Journal of Cereal Science, vol. 85, pp. 221-227, 2019.

[25] B. Mathpal, P. Srivastava, D. Shankhdhar, and S. Shankhdhar, "Zinc enrichment in wheat genotypes under various methods of zinc application," Journal of Plant, Soil and Environment, vol. 61, pp. 171-175, 2015.

[26] M. U. Chattha, M. U. Hassan, I. Khan et al., "Biofortification of wheat cultivars to combat zinc deficiency," Frontiers in Plant Science, vol. 8, p. 281, 2017.

[27] D.-Y. Liu, W. Zhang, L.-L. Pang et al., "Effects of zinc application rate and zinc distribution relative to root distribution on grain yield and grain $\mathrm{Zn}$ concentration in wheat," Plant and Soil, vol. 411, no. 1-2, pp. 167-178, 2017.

[28] A. Hussain, H. Larsson, R. Kuktaite, and E. Johansson, "Mineral composition of organically grown wheat genotypes: contribution to daily minerals intake," International Journal of Environmental Research and Public Health, vol. 7, no. 9, pp. 3442-3456, 2010.

[29] A. H. Khoshgoftarmanesh, M. Afyuni, M. Norouzi, S. Ghiasi, and R. Schulin, "Fractionation and bioavailability of zinc (Zn) in the rhizosphere of two wheat cultivars with different $\mathrm{Zn}$ deficiency tolerance," Geoderma, vol. 309, no. 1-6, 2018. 